TERMINUS

t. $22(2020)$

z. $3(56)$

s. $187-208$

www.ejournals.eu/

Terminus

\title{
to Jacobus Pontanus
}

\section{and the Tradition of Antiquity}

\section{Abstract}

The aim of this study is to present the findings of a comparative analysis that coverson the one hand-the theory of tragedy presented in Poeticarum institutionum libri III by Jakob Pontanus (Spanmüller), the classical and Renaissance poetics and commentaries on which he based his work, as well as the ancient tragedies that belonged to the literary canon in Jesuit colleges, and-on the other hand-Pontanus's theoretical approach mentioned above and his tragedy Elezarus Machabaeus.

The works of Pontanus have previously been discussed by Joseph Bielmann. However, Bielmann did not present them against the background of the Greek and Roman tragedies or the statements of the ancient theorists on drama, the Renaissance theoretical reflection on tragedies, or the playwriting practice resulting from this reflection. Consequently, his characterisation of the Elezarus Machabaeus is untenable, and his comments on Pontanus's theory of drama need reviewing. Determining whether Pontanus respected the rules of ancient tragedy or whether he openly violated them is important because he was one of the most outstanding Jesuit humanists and a person of authority in his community. If we take into account the fact that Elezarus Machabaeus was the first tragedy printed by the Jesuits, the Poeticarum institutionum libri tres was one of the first printed Jesuit textbooks of this kind, and Pontanus himself was also the author of other books recommended for reading in Jesuit colleges and participated in the work of the committee for the evaluation and approval of the Jesuit school act, his views on the imitation of ancient models should be considered influential at least to a moderate degree and at least in some literary circles of his time. This matter is addressed in the introductory part of this paper. It also contains a short presentation of Pontanus's textbook against the background of other Jesuit poetics, as well as of his main sources in the field of drama theory. Subsequently, the author presents Pontanus's concept of drama and then discusses his piece taking into account the context of ancient and contemporary drama theory and practice of writing.

In the light of this comparative reading, Eleazarus Machabaeus seems to be generally based on ancient models despite certain peculiarities, such as the composition and absence of choruses, which may be surprising at first. Both Pontanus's tragedy and his theoretical approach should be regarded as classical in nature.

\section{Keywords}

Jesuit drama theory, Jesuit tragedy, reception of ancient tragedy, Jakob Pontanus, Eleazarus Machabaeus 
As pointed out by Jozef IJsewijn in the introduction to his discussion of Jesuit poetics, the dynamic development of Latin drama between the 16th and 18th centuries was largely due to the activity of the fathers of the Society of Jesus, both in the area of praecepta and in the area of usus. ${ }^{1}$ The term praecepta can, in this context, be used to refer not only to publications that collected and systematised information about drama as a genre but also to the knowledge transmitted at school during the reading of ancient tragedies and comedies, both Latin and Greek. For Jesuit scholars, these pieces $^{2}$ were as important a source of information about dramatic genres as treatises by Aristotle, Horace, Donatus, Euanthius, Diomedes, and poetics by Renaissance authors. One of the earliest Jesuit studies of the dramatic genre available in print ${ }^{3}$ was included in the poetics by Jacobus Pontanus (Spanmüller) SI (1542-1626). ${ }^{4}$ It

$1 \quad$ Jozef IJsewijn, "Symbola ad studium theatri Latini Societatis Iesu", Revue Belge de Philologie et d'Histoire 43 (1965), no. 3, p. 946.

2 Tragedies by Seneca, Sophocles, and Euripides were included in the school syllabus by the Jesuit Ratio studiorum of 1591 (Ratio atque institutio studiorum, Roma: Collegium Societatis Iesu, 1591, pp. 279, 306). The set reading lists for particular provinces recommended tragedies by Seneca and occasionally also by Euripides and Sophocles; see, e.g., "Catalogus librorum quinto quoque anno recurrens" (1604), “Catalogus quinquennalis” (1604, 1606, 1607, 1629, 1630, 1631, 1632, 1633, 1634), in Georg Michael Pachtler, Ratio studiorum et institutiones scholasticae Societatis Iesu per Germaniam olim vigentes collectae, concinnatae, dilucidatae, vol. 4, Berlin 1894, pp. 2, 6, 9, 10, 25-29; “Catalogus triennalis" (1616-1622) in Ordinationes praepositorum generalium, provincialium, visitatorum et responsa Romana Provinciae Polonae et Litvaniae saeculis XVI-XVII data, Archivum Societatis Iesu Cracoviense, 496, pp. 911-919; François de Dainville, Léducation des Jésuites (XVIe-XVIII siècles), ed. by Marie-Madelaine Compère, Paris 1978, p. 283. In his poetics treatise, Pontanus mentions Plautus and Terence as models to imitate in the area of comedy, and Seneca and Euripides in the area of tragedy: Jacob Pontanus, Poeticarum institutionum libri III. Editio tertia cum auctario, et indice hactenus desiderato. Eiusdem Tyrocinium poeticum cum supplemento, Ingolstadt: Adam Sartorius, 1600, pp. 29-30.

3 Apart from the works by Delrío and Pontanus; Biblioteca selecta by Antonio Possevino (which provides no substantial discussion of dramatic genre: Antonio Possevino, Bibliotecae selectae pars secunda, Roma: Typographia Apostolica Vaticana, 1593, pp. 277-278); the third part of Tractatus VII by Juan de Mariana (Köln: Anton Hierat, 1609), focusing on the performance rather than on poetics; and various prefaces to printed dramas with remarks on poetics, these are: Tarquinio Galluzzi, Virgilianae vindicationes et Commentarii tres de tragoedia, comoedia, elegia, Roma: Alessandro Zanetti, 1621; Alessandro Donati, Ars poetica, Roma: Guglielmo Faciotti, 1631; Jakob Masen, Palaestra eloquentiae ligatae, dramatica quae complectitur, Köln: Jan Buys, 1657 (ed. princ. 1645); Martin du Cygne, De arte poetica libri duo, Liège: Vidua Balduini Bronckart, 1664; [Joseph de Jouvancy], Christianis litterarum magistris de ratione discendi et docendi, Paris 1692 (ed. princ. 1691); [id.], Institutiones poeticae, Venezia: Nicolò Pezzana, 1718; François Noël, Synopsis praeceptorum tragoediae, in id., Opuscula poetica, Frankfurt: Thomas Fritsch, 1717; Gabriel François Le Jay, Bibliotheca rhetorum praecepta et exempla complectens quae ad poeticam facultatem pertinent, Paris: Grégoire Du Puis, 1725; Franz Lang, Dissertatio de actione scenica, München: Maria Magdalena Riedl, 1727; Franz Neumayr, Idea poeseos, Ingolstadt: Johann Paul Schleig, 1751; Ignaz Weitenauer, Q. Horatii Flacci Ars poetica, ad omne genus eloquentiae, ligatae, solutae, etiam sacrae, accommodata, Augsburg and Freiburg im Breisgau: Ignatius et Antonius Wagner, 1757. Selected problems of poetics, including drama, are also discussed, albeit not systematically, in Famiano Strada, Prolusiones academicae, Roma: Giacomo Mascardi, 1617. See IJsewijn, Symbola ad studium theatri, pp. 947-956. Born in Brüx (present-day Most in the north-western part of the Czech Republic, Lat. Pons), Pontanus joined the Society of Jesus in 1563 . He developed his literary interests teaching poetics and rhetoric in 
was only predated by a year by a treatise on tragedy ${ }^{5}$ appended by Martín Antonio Delrío SI (1551-1608) ${ }^{6}$ to his edition of Seneca's plays, and by more than a decade by De poetica libri tres by Giovanni Antonio Viperano (1535-1610), ${ }^{7}$ a former Jesuit. For Pontanus, the latter work was the main source of knowledge on drama, ${ }^{8}$ although he departed from it in some respects. ${ }^{9}$ Pontanus was also the author of the first printed Jesuit tragedy, Eleazarus Machabaeus (its plot-the eponymous hero is executed for refusing to break Jewish law-was taken from the Old Testament: 2 Macc. 6), included in his extended Tyrocinium, a supplement to the third edition of Poeticarum institutionum libri III, ${ }^{\mathbf{1 0}}$ which comprised a selection of various poetic genres. Eleazarus,

Dillingen an der Donau (1570-1579) and later (since 1582) in the college he founded together with Wolfgang Starck SI (1554-1605) in Augsburg, where he died. It was in the Augsburg years that he published texts that brought him most renown, including Progymnasmata Latinitatis, Attica bellaria, and the work discussed in this paper. It is worth pointing out that, as a supporter of the humanistic model of teaching in the colleges of Societas Iesu, Pontanus participated in works of the committee for the evaluation and approval of the Jesuit school act, proclaimed in its final version in 1599, after the 1585 and 1591 editions. The life of Pontanus with a short discussion of his work is presented in Paul Richard Blum, "Jacobus Pontanus SJ", in Deutsche Dichter der frühen Neuzeit (1450-1600). Ihr Leben und Werk, ed. by Stephan Füssel, Berlin 1993, pp. 626-635; Ulrich G. Leinsle, "Jacobus Pontanus SJ (1542-1626). Humanismus und 'pietas' in der Spätrenaissance”, Beiträge zur Geschichte des Bistums Regensburg 43 (2009), pp. 81-99; see also Barbara Mahlmann-Bauer, "Jakob Pontanus in Augsburg. Seine Schülergespräche, seine Poetik und sein Drama 'Opferung Isaaks”', in Jakob Bidermann und sein „Cenodoxus”. Der bedeutendste Dramatiker aus dem Jesuitenorden und sein erfolgreichstes Stück, ed. by Helmut Gier, Regensburg 2005, pp. 15-59; Fiedel Rädle, "Jesuit Theatre in Germany, Austria and Switzerland", in Neo-Latin Drama and Theatre in Early Modern Europe, ed. by Jan Bloemendal and Howard B. Norland, Leiden and Boston 2013, pp. 266-268.

$5 \quad$ Martín Antonio Delrío, Syntagma tragoediae Latinae in tres partes distinctum, Antwerpen: Veuve de Christophe Plantin, Jan Moretus, 1593.

6 Carlos Sommervogel, Bibliothèque de la Compagnie de Jésus. Bibliographie, Brussels and Paris 18901932, vol. 2, col. 1894-1905.

$7 \quad$ Giovanni Antonio Viperano, De poetica libri tres, Antwerpen: Christophe Plantin, 1579. Viperano probably wrote it when he was still a member of Societas Iesu (before 1561), but the work was not published until he had stepped out of the society; IJsewijn: Symbola ad studium theatri, pp. 948-951.

8 Apart from Viperano's treatise, Pontanus (cf. Poeticarum institutionum libri III. Editio tertia, fol. 8v unnumb.) could use the following sources (only those that discuss dramatic genres are listed here): poetics by Aristotle and Horace (Aristoteles Poetica; Horatius Ars poetica), Aelius Donatus' commentary on Terence (Donatus Ad Terentii Adriam; De comoedia), Cicero's remarks, books III and IV of Minturno's poetics (Antonio Sebastiano Minturno, De poeta, Venezia: Francesco Rampazetto, 1559), Robortello's and Vettori's commentaries on Aristotle (Francesco Robortello, In librum Aristotelis de arte poetica explicationes, Firenze: Lorenzo Torrentino, 1548; Pietro Vettori, Commentarii in primum librum Aristotelis de arte poetarum, Firenze: Filippo Giunto, Bernardo Giunto, Jacopo Giunto, Julio Giunto, 1560), and the poetics by Scaliger (Julius Caesar Scaliger, Poetices libri septem, [Lyon]: Antoine Vincent, 1561). On the above-mentioned poetics and Renaissance commentaries, Marvin Carlson, Theories of the Theatre: A Historical and Critical Survey from the Greeks to the Present, Ithaca and London 1984, pp. 38-40, 43-47.

9 Among other, Pontanus ignores the issue of the tragic chorus as well as Aristotle's definition of the tragic character, and does not identify the tragic prologue with protasis, pp. 6-8.

10 This is why all references in this paper are to this specific edition (rather than to ed. princ.: Jakob Pontanus, Poeticarum institutionum libri tres. Eiusdem Tyrocinium poeticum, Ingolstadt: David Sartorius, 
the only tragedy among the preserved plays of Pontanus, was discussed by Joseph Bielmann, who also presented the theory of drama developed in Poeticarum institutionum libri. ${ }^{11}$ Bielmann summarised the tragedy and compared Pontanus' theoretical approach with some Renaissance concepts of drama on which the Jesuit writer must have based. However, he did not situate Eleazarus in the context of ancient texts; as a result, he ignored or only cursorily commented ${ }^{\mathbf{1 2}}$ on certain unique elements of the play and Pontanus' theory of the genre. Ultimately, he described it as a Renaissance drama with a baroque plot. ${ }^{13}$ This appears to be a simplification with respect to both the form and the plot of the work, which bears analogy to such ancient plays based on the heroic death motif as, for instance, Seneca's Troades and Hercules Oetaeus. Especially the form of Eleazarus calls for a critical discussion in the context of Pontanus' theoretical comments and ancient tragedies, a discussion which may help establish whether Pontanus - one of the most outstanding humanists in this community, a supporter of education based on knowledge of the ancient literary canon, ${ }^{\mathbf{1 4}}$ and the author of a poetics which for a quarter of a century remained the only Jesuit textbook of this type-actually recommended following ancient genre models, or, conversely, departing from them freely.

1594), unless otherwise indicated. The chapters on comedy and tragedy differ only slightly between the editions, and the changes introduced do not concern the problems discussed here.

The decades that followed the publication of Pontanus' poetics saw a growing number of such Jesuit studies; it is therefore not surprising that after 1630, only one edition was released (1670). However, earlier it was reissued several times, which may be taken as an indirect indicator of its popularity. It was recommended for school use (or its abridged version edited by Buchler) in colleges; Pachtler, Ratio studiorum, pp. 191, 201. Also Blum, Jacobus Pontanus, p. 630. According to Sommervogel (Bibliothèque, vol. 6, col. 1011-1012), subsequent editions of Poeticarum institutionum, published after ed. princ. of 1594, appeared in 1597, 1600 (Ingolstadt), 1600 (Tournon-sur-Rhône), 1600 (Avignon), 1604 (Limoges), 1609 (Poitiers), 1613, 1620 (Lyon), and 1630 (Douai). Additionally, its shorter version, condensed by Buchler, was released seven times in the years 1602-1805.

11 Joseph Bielmann, "Die Dramentheorie und Dramendichtung des Jakobus Pontanus S.J. (1542-1626)", Literaturwissenschaftliches Jahrbuch der Görres-Gesellschaft 3 (1928), pp. 45-85. Specifically on Elezarus Machabaeus, ibid., pp. 64-69.

12 In Bielmann's view (ibid., p. 66), the prologue to Eleazarus is justified in the light of theoretical remarks made by Pontanus. Moreover, he associates the lack of mention of tragic choruses in Pontanus (ibid., p. 63) with the author's comment that singing (melopoeia) is a redundant element of drama (Pontanus, Poeticarum institutionum libri III. Editio tertia, p. 93). He suggests (Bielman, Dramentheorie und Dramendichtung, p. 63) that this omission may result from the fact that Pontanus excludes singing from the realm of poetry (in much the same way as Aristotle excludes performance: Aristoteles Poetica 1450b). Still, this explanation does not appear convincing. A comparison of Pontanus' remarks with Viperano (De poetica, p. 121) demonstrates that Pontanus uses the term melopoeia to refer to the comic chorus, absent from New Comedy, which is why he considers discussing it as superfluous. His comment, however, cannot be taken to apply to the tragic chorus. Moreover, as Bielmann (Dramentheorie und Dramendichtung, p. 63) himself observes, according to the sources which served as the basis for Pontanus, the chorus always appears in tragedy (cf. p. 194).

13 Bielmann, Dramentheorie und Dramendichtung, p. 69, see also n. 75.

14 See n. 4. 


\section{The theoretical approach}

Of the problems discussed by Pontanus, this paper will consider the following: 1) the definition of tragedy; 2) art reception, including the concept of catharsis; 3) basic and formal elements in art; 4) tragic and comic characters, together with the number of stage characters; and 5) the time of action, the representation of brutal elements on stage, the presence of superhuman characters, and the stylistic form of the text.

Ad 1) Pontanus borrows the definition of the genre from Viperano, who, in turn, draws on Aristotle's definition. ${ }^{15}$ The basic criterion to distinguish between tragedy and comedy is the social position of the hero, combined with the main theme of the work (tragedy concerns events that evoke compassion and terror, such as death, mourning, torment, murder, or despair, ${ }^{\mathbf{1 6}}$ while comedy intertwines hardships with fortunate events ${ }^{\mathbf{1 7}}$ ) and the type of emotions stirred in the receiver, together with the cognitive and didactic function of the play which follows from them:

Tragoedia est poesis virorum illustrium per agentes personas exprimens calamitates, ut misericordia et terrore animos ob iis perturbationibus liberet, a quibus huiusmodi facinora tragica proficiscuntur. ${ }^{18}$

[Tragedy is a genre of poetry which, through acting characters, shows the calamities of illustrious people in order to free the human mind - through compassion and terror-from the confusion which is responsible for such tragic events. ${ }^{19}$

Comoedia est poesis dramatica, quae ob docendam vitae consuetudinem, civiles et privatas actiones, non sine leporibus et facetiis imitatur. ${ }^{20}$

[Comedy is a genre of dramatic poetry which, in order to instruct, imitates actions of private people, not without charm or wit.]

It is worth pointing out that according to this definition, events evoking compassion and terror need not appear in the concluding part of the play; ${ }^{\mathbf{2 1}}$ a similar opinion is expressed by Italian literary theoricians Antonio Sebastiano Minturno ${ }^{\mathbf{2 2}}$ and, later, Jesuit Tarquinio Galluzzi, who claims that the goal of tragedy (finis) cannot be

15 See also Bielmann, Dramentheorie und Dramendichtung, pp. 50-51.

16 Pontanus, Poeticarum institutionum libri III. Editio tertia, pp. 110, 113-114; cf. Viperano, De poetica, p. 96.

17 Pontanus, Poeticarum institutionum libri III. Editio tertia, p. 94; cf. Viperano, De poetica, pp. 121-124.

18 Pontanus, Poeticarum institutionum libri III. Editio tertia, p. 108; cf. Viperano, De poetica, p. 94.

19 All translations from Latin are by the author of the article.

20 Pontanus, Poeticarum institutionum libri III. Editio tertia, p. 87; cf. Viperano, De poetica, p. 120.

21 Pontanus, Poeticarum institutionum libri III. Editio tertia, p. 110.

$22 \quad$ Minturno, De poeta, p. 189. 
identified with the conclusion of the plot (exitus et clausula fabulae). ${ }^{23}$ By contrast, Italian Jesuit Alessandro Donati, ${ }^{\mathbf{2 4}}$ among others, following his compatriot Julius Caesar Scaliger ${ }^{25}$ and several remarks by Aristotle, ${ }^{26}$ defines tragedy through the unhappy ending-although, like Scaliger, expresses some reservations in this regard. ${ }^{27}$ In fact, defining tragedy as a drama with an unhappy ending is problematic in that this definition hardly applies to some ancient tragedies or to a large number of 16th- and 17th-century plays, in particular, tragedies with martyr characters. Still, the conflict between the two approaches cannot be viewed in terms of respecting or rejecting ancient tradition. Scaliger and Donati adopt a definition which applies well to many ancient tragedies and, in addition, is based on some comments made by Aristotle but remains independent of his definition of the genre. ${ }^{28}$ On the other hand, the definition adopted by Viperano, Pontanus, and Galuzzi partly coincides with the Aristotelian definition and is generally consistent with his approach, at the same time comprising plays whose endings cannot be classified as unhappy but which nevertheless are traditionally subsumed under the term tragedy, such as Euripides' Ion, Helena, Electra, and Orestes, ${ }^{29}$ and, among Latin texts, Hercules furens and Hercules Oetaeus. Thus, all these authors prioritise the immanent poetics of ancient plays over the Aristotelian view and are well aware of the weaknesses in the philosopher's exposition. ${ }^{30}$ One may also come to the conclusion that, without explicitly abandoning the model of ancient tragedy, Pontanus (but not Viperano ${ }^{\mathbf{3 1}}$ ) ignores another Aristotelian principle: one according to which a tragic hero cannot be of unblemished virtue but must suffer misfortunes brought upon him by his own error-a condition that is not satisfied by, among others, martyr characters. Actually, a polemic against this principle appeared earlier, in Minturno's poetics, where one of the interlocutors pointed to the fact that it was not satisfied, for instance, in Euripides' Heraclidae. ${ }^{32}$

Galluzzi, Virgilianae vindicationes, pp. 318-320.

24 Donati, Ars poetica, p. 128.

25 Scaliger, Poetices libri septem, pp. 11-12.

26 Aristoteles Poetica 1453a.

27 In Book Three of his work, Scaliger (Poetices libri septem, p. 145) mentions tragedies which do not have a clearly unhappy ending, but he does not modify the definition of tragedy presented in Book One. Donati (Ars poetica, pp. 162-166) believes that such a resolution, if added to the usual, that is, unhappy ending, serves to console the receiver. Cf. also Minturno, De poeta, p. 188.

28 Cf. Aristoteles Poetica 1449b.

29. These plays are given as examples by both Viperano (De poetica, p. 97) and Pontanus (Poeticarum institutionum libri III. Editio tertia, p. 110).

30 Pontanus' remark in his preface to the reader: "Aristotelis quidem in hoc genere monumenta, praeterquam quod obscuritate sua lectorem reiciunt, etiam mutila et imperfecta sunt deque tragoedia duntaxat loquntur" [Aristotle's treatise of this kind, apart from the fact that it deters the reader with its obscurity, is fragmentary and incomplete, and it deals only with tragedy], Pontanus, Poeticarum institutionum libri III. Editio tertia, fol. )(2r.

31 Viperano, De poetica, p. 97.

32 Minturno, De poeta, pp. 180, 182-184. Also Bielmann, Dramentheorie und Dramendichtung, pp. 58-59. 
Ad 2) A remarkable element in the definition of tragedy above is the free interpretation of the Aristotelian concept of catharsis, adopted not from Italian commentators on Aristotle, Francesco Robortello ${ }^{33}$ or Pietro Vettori, ${ }^{34}$ but from Minturno. ${ }^{35}$ Viperano, and Pontanus after him, distinguishes between the cathartic power of tragedy on the one hand, connected with the feelings of compassion and terror it evokes, and the pleasure it gives as a poetic genre, on the other. Pontanus discusses the latter problem in somewhat more detail than Viperano, ${ }^{36}$ apparently inspired by some passages from Aristotle's Poetics. Thus, one cannot treat this approach as an attempt to abandon the ancient theory of drama; rather, it offers a reinterpretation of its particularly obscure fragments. Pontanus explains that the specific pleasure experienced by the receiver of tragedy is in fact the same kind of pleasure as the one experienced by the receiver of mimetic art in general, that is, it is produced not by the tragic object but by its imitation. ${ }^{37}$ Moreover, the pleasure follows from admiration for the artist, from the distance towards the compassion- and terrorproducing object (the misfortunes we lament are not ours), ${ }^{38}$ from the fact that compassion is part of human nature, and from the edifying potential of tragedy, which instructs ${ }^{39}$ what to avoid. ${ }^{40}$

Ad 3) With regard to the elements of drama, the author draws largely from Viperano but discusses only the elements of comedy, adding a comment that, except for the prologue, they apply also to tragedy. ${ }^{41}$ Specific points of his discussion are based on ancient sources. The general division into basic elements (partes qualitatis) - plot, characters, thought, diction, spectacle, and song (fabula, mores, sententia, dictio, apparatus, melodia) —and formal elements (partes quantitatis) ${ }^{\mathbf{4 2}}$ is consistent with Aristotle's approach. ${ }^{43}$

With regard to the composition of drama, ancient theorists mention three pos-

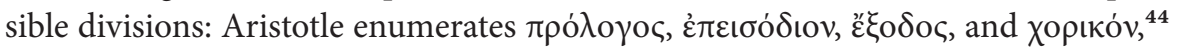
in a more systematic way than Viperano-as does Minturno; Minturno's treatise is, however, more detailed, and his terminology is different (Minturno, De poeta, pp. 186-244, 282-353). In this respect, Pontanus does not follow Scaliger, either, who proposes somewhat different divisions; Scaliger, Poetices libri septem, pp. 14-15, 18-19.

43 Aristoteles Poetica 1450a-1450b, 1452b.

44 Aristoteles Poetica 1452b. 
Horace and Donatus ${ }^{45}$ mention five acts, and Donatus and Euanthius ${ }^{46}$ talk about

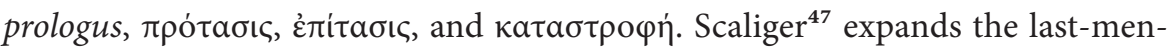
tioned division to include catastasis, which later authors include as well. Viperano refers to all three divisions and emphasises that in tragedy, prologus corresponds to protasis, and catastrophe to exodus. ${ }^{48}$ Pontanus only makes reference to the last two divisions and, like Viperano, puts emphasis on the difference between comic and tragic prologues: both in tragedy and in comedy, the prologue is often delivered by persona protatica, ${ }^{49}$ but in contrast to the comic prologue, the prologue in tragedy is always motivated by the plot; it is mimesis of an action (as an example, the author quotes Polydorus' words from Euripides' Hecabe). ${ }^{50}$ By contrast, Spanmüller does not identify the tragic prologue with protasis. Instead, he points out that its main function is to capture the receiver's interest rather than to introduce prior events, since, unlike in the case of comedy, the plot in tragedy is usually wellknown. ${ }^{51}$ After the prologue, the author mentions protasis as the first element of the plot, which encompasses the first or the first and second act and serves to introduce the theme; epitasis, which presents the conflict; and catastasis, where the conflict is heightened (both span over the second and third act, sometimes also over the fourth and part of the fifth act). At the end, in the fourth or fifth act, there is catastrophe, which comprises the climax and the resolution. ${ }^{52}$ With regard to the division into acts, Pontanus remarks that it is possible to identify the beginning of an act with the appearance of a new character, ${ }^{53}$ or to accept a division which reflects the order of the plot: act one introduces the theme; the plot commences in act two; in act three, adversities appear; act four opens the way for the resolution; and act five brings the resolution of the plot. ${ }^{54}$ Finally, unlike Viperano, who discusses the tragic chorus in greater detail, ${ }^{55}$ Pontanus ignores it altogether and refers to the comic chorus only in a historical perspective. ${ }^{56}$

Ad 4) Pontanus describes tragic heroes as "illustres viri, illustres feminae, principes, reges, imperatores" [illustrious men and women, leaders, kings, and imperators], ${ }^{57}$

45 Horatius Ars poetica 189-190; Donatus Ad Terentii Adriam, praef. 3, 1-5.

46 Donatus De comoedia 7, 1-4; Euanthius 4, 5.

47 Scaliger, Poetices libri septem, pp. 14-15.

48 Viperano, De poetica, pp. 102-110, 125-128.

$49 \quad$ A term used by Donatus to refer to a character who speaks in the prologue but does not take part in the plot; Donatus, Ad Terentii Adriam, praef. 1, 8.

50 Pontanus, Poeticarum institutionum libri III. Editio tertia, pp. 100-101, 112; cf. Viperano, De poetica, p. 102.

51 Pontanus, Poeticarum institutionum libri III. Editio tertia, p. 112; cf. Viperano, De poetica, p. 102.

52 Pontanus, Poeticarum institutionum libri III. Editio tertia, p. 101; Viperano, De poetica, pp. 107, 126-128.

53 Donatus, who mentions difficulties with the division of Latin comedies into acts, points out that the end of an act is marked by the absence of characters on stage; at this point, the chorus can appear; Donatus, Ad Terentii Adriam, praef. 2, 3. Also Viperano, De poetica, p. 127.

54 Pontanus, Poeticarum institutionum libri III. Editio tertia, p. 102; Viperano, De poetica, pp. 109-110, 128.

55 Viperano, De poetica, pp. 108-109.

56 Pontanus, Poeticarum institutionum libri III. Editio tertia, pp. 90-91; Viperano, De poetica, p. 125.

57 Pontanus, Poeticarum institutionum libri III. Editio tertia, p. 114; cf. Viperano, De poetica, p. 96. 
and comic characters as "ignobiles, obscurae, civiles" [low and unknown private people]. ${ }^{58}$ Referring to Horace, ${ }^{59}$ he recommends that well-known characters, especially those in tragedy, should correspond to their existing image. By contrast, if heroes are made up for the sake of a single play, as is often the case in comedy, they should be credible, that is, they should represent typical human characters, such as an old man, a mature man, a youth, or a child. The characters should not change throughout the play, unless there are circumstances that could justify it. ${ }^{60}$ Pontanus also mentions the Horatian principle ${ }^{61}$ according to which one scene should contain no more than three characters, and if four are present, one of them should be silent, but he points out that Plautus violates it, as do tragedians. ${ }^{62}$ He does not provide any examples, perhaps merely relying on Viperano. ${ }^{63}$ Nevertheless, such examples can be found, for instance, in Seneca's Hercules furens, where one scene contains four speaking characters-Hercules, Amphitryon, Megara, Theseus-and Hercules' (silent) children. ${ }^{\mathbf{6 4}}$

Ad 5) With regard to the time of action, both Viperano and Pontanus ${ }^{65}$ indicate that it should be confined to, or only slightly exceed, one day, thus maintaining the Aristotelian principle. ${ }^{66}$ They refer to Horace ${ }^{67}$ when they observe that representation of brutal, drastic, or too extraordinary elements on stage is inappropriate, but they admit that it is not a commonly held opinion and that the opposite point of view finds support in preserved ancient examples. ${ }^{68}$ Similarly, they base on Horace's authority ${ }^{69}$ when they excuse the introduction of superhuman characters into a play if it is necessary to communicate matters that are beyond the cognitive capacity of the heroes or,

Pontanus, Poeticarum institutionum libri III. Editio tertia, p. 114; cf. Viperano, De poetica, p. 121.

Horatius Ars poetica 119-127, 156-178.

Pontanus, Poeticarum institutionum libri III. Editio tertia, pp. 96-98; cf. Minturno, De poeta, p. 239. Horatius Ars poetica 192.

Pontanus, Poeticarum institutionum libri III. Editio tertia, p. 104.

Viperano, De poetica, p. 92: "Sophocles ... tres personas (ut vult Aristoteles) inter se colloquentes induxit (quamquam tres etiam saepe apud Aeschylum apparent et interim apud omnes quattuor)" [According to Aristotle, Sophocles introduced three characters conversing with each other (although we also often find three characters in Aeschylus, and they all sometimes introduce four).]

Seneca Hercules furens 895-1053, and in particular 1032-1034-these lines are attributed to Theseus in most manuscripts of Seneca's tragedies (EA-tradition; see n. 85); only one codex attributes them to the chorus (Ambrosianus, Biblioteca Ambrosiana, Milano, D 276 inf., 14th century, Italia); the chorus is also mentioned instead of Theseus in the heading of this scene in codex Etruscus (which represents E-tradition). Most importantly in the context of this discussion, in the 16th-century editions of Seneca's tragedies (see n. 88), for instance, in the Delrío edition, these lines are spoken by Theseus; In L. Annaei Senecae Cordubensis poetae gravissimi Tragoedias decem ... amplissima adversaria, ed. et comm. Martín Antonio Delrío, Antwerpen: Christophe Plantin, 1576.

Pontanus, Poeticarum institutionum libri III. Editio tertia, pp. 94, 112; Viperano, De poetica, pp. 102, 129.

Aristoteles Poetica 1449b.

Horatius Ars poetica 182-188.

Pontanus, Poeticarum institutionum libri III. Editio tertia, p. 111; Viperano, De poetica, p. 99.

Horatius Ars poetica 191-192. 
in exceptional cases, to resolve the plot. $^{70}$ The authors refer also to Horace's poetics ${ }^{71}$ in their discussion of style in tragedy: solemn, elevated, sententious, and remote from everyday diction, which, however, is acceptable when expressing a complaint. This is reverse in the case of comedy, where a more elevated style is justified, for instance, in a tirade; otherwise, the diction should be common and unadorned. ${ }^{72}$ Additionally, Pontanus makes some observations concerning the rule for drama titles. They are taken from the name of a place, something related to the plot of the play, or-most frequently-the main character. ${ }^{73}$

\section{Eleazarus Machabaeus and ancient models}

Compositionally, Eleazarus follows the rules for tragedy that Pontanus sets forth in his poetics with regard to the title (Eleazarus is the name of the main character), the status of the protagonist (an excellent priest and an authority among his community members), his representation, which generally corresponds to the Biblical image of Eleazar, ${ }^{74}$ and his suffering and death. The author complies with the recommendations concerning the time of action (it is confined to one day) and the language (the style is solemn, rather sententious, and moderately ornate). In some dialogues, the number of speakers exceeds three, but in Pontanus' view, it does not violate the rules of the genre. Drastic content (the martyr's death) is presented in narrative parts, and the superhuman character (Idolomania) discloses the sense of the events that is beyond the cognitive powers of other characters. The distribution of plot elements closely follows the rules. Act one contains a detailed presentation of events that precede the action and their interpretation from the perspective of Eleazar and his companion, which corresponds to the introduction into the plot. Past events are also referred to at the beginning of act two: these reminiscences make Eleazar's antagonist, Antiochus, intensify persecution against Jews. In this act, two Jewish dissenters inform on Eleazar to gain Antiochus' support; as a result, the king will first act against the priest. In this way, the plot is commenced, with protasis slightly postponed beyond act one. In act three, Eleazar is captured, disobeys Antiochus, and is sentenced to flogging and next to the stake, which builds the dramatic tension: epitasis. In act four, after Eleazar is flogged, his friends attempt to persuade him to pretend to yield to Antiochus, and so to save life. Eleazar refuses and decides to die, which opens the way to resolution, while the dramatic tension

71 Horatius Ars poetica 89-98.

72 Pontanus, Poeticarum institutionum libri III. Editio tertia, pp. 111-112, 114; Viperano, De poetica, pp. 100, 124.

73 Pontanus, Poeticarum institutionum libri III. Editio tertia, pp. 115-116.

742 Macc. 6: 18-31.
} 
reaches the highest point: catastasis. In act five, the Messenger reports on Eleazar's execution. His death is presented as a voluntary sacrifice for the sins of the Israeli people and a praiseworthy example. In this way, the plot is resolved in catastrophe. ${ }^{75}$

On the other hand, the lack of choruses and the nature of the prologue-which precedes act one as a distinct part, a practice unknown in 16th-century editions of Roman tragedies, at that time divided into five acts-seem, at first glance, to break with ancient tradition. One might conclude that the author introduces into his tragedy some features characteristic of New Comedy. This conclusion, however, does not appear well-founded, since Pontanus, as demonstrated above, complies with other generic rules. Moreover, in his poetics, he draws attention to the differences between the tragic and comic prologues and bears them in mind while writing the prologue to Eleazarus. He introduces persona protatica, but this solution is motivated by the plot, and the monologue by persona protatica does not break the rules of illusion, as is the case in comic prologues. The function of the prologue is to introduce the receiver to events that precede the action of the play, but from a different perspective than that taken by the heroes in protasis. ${ }^{76}$ As a result of the choice of the character-superhuman and powerful, but with a limited ability to influence or anticipate events to come-the prologue bears a close similarity to Seneca's prologue in Hercules furens. ${ }^{77}$ Thus, it would seem that in moving the prologue before act one, Pontanus does not intend to violate the rules of the genre but takes into consideration other reasons.

Parts of Greek and Roman tragedies which can be identified with prologues are separated from other segments of the play by the chorus. The majority of Greek tragedies, as pointed out by Scaliger, comprise six act-like segments, ${ }^{78}$ or five, if one excludes the prologue. Thus, although in the plays attributed to Seneca, the prologue can be identified with the first of five acts, in times of heightened interest in ancient literature, differences in this respect between Greek and Roman tragedy may have prompted attempts to reconcile the two traditions. This, in turn, may have led to the

75 Jacob Pontanus, Eleazarus Machabaeus. Tragoedia sacra, in id., Poeticarum institutionum libri III. Editio tertia, pp. 507-556. Bielmann (Dramentheorie und Dramendichtung, pp. 68-69) argues that the plot of Eleazarus is focused on the death of the main character, and because the death is only reported at the end of the play, with the climax taking place earlier, he proposes that the work bears traces of baroque asymmetry. This interpretation, however, does not seem well-grounded; one may well assume that the plot is focused on Eleazar's conscious decision to die a martyr's death, so the moment of decisionmaking is the culminating point of the action. His martyrdom is a result of this decision and can be identified with the resolution. It is worth pointing out that, in terms of the development of the plot, Pontanus' approach tallies with, for instance, Seneca's Troades and Hercules Oetaeus.

76 Cf. p. 196.

77 In the prologue, Iuno (Seneca Hercules furens 107-121) hints that in order to take revenge on Hercules, she will send him a sudden madness and lead him to murder, but she makes no mention of the fact that, with the help from Amphitryon and Theseus, the hero will overcome despair and will be promised absolution (Seneca Hercules furens 1314-1344), cf. Richard John Tarrant, "Commentary", in Seneca, Agamemnon, ed. with a comment. by Richard John Tarrant, Cambridge 1976, p. 158.

78 Scaliger, Poetices libri septem, p. 146. 
emergence of an abstract model according to which a tragedy consists of five acts, excluding the prologue. Interestingly, although in the 16th century, like today, Greek tragedies were not segmented into acts, in the Greek and Latin Basel edition (1562) of the plays of Euripides ${ }^{79}$ - whose works, alongside Seneca's plays, Pontanus regards as models ${ }^{\mathbf{8 0}}$ - texts were divided into five acts, with the prologue placed before act one as a separate part. ${ }^{81}$ Moreover, markings of acts were also added in handwriting to the text of some tragedies in a copy of the 1544 Greek Basel edition of Euripides found in the Jesuit Collegium Romanum. ${ }^{82}$ A still different division of Greek tragedies into five acts was proposed by Minturno. According to him, act one embraces the prologue, parodos, and the first stasimon. ${ }^{83}$ Pontanus might also have been aware of the fact that the division of Roman tragedies into acts was introduced by critics and editors and hence resulted from interpretation of texts; it can be found in Nicholas Trevet's commentary (dated back to $1313-1317)^{\mathbf{8 4}}$ and in many secondary manuscript copies, but it is absent from the earliest manuscripts. ${ }^{85}$ Acts are not distinguished in the Gallicus edition (1484?), ${ }^{86}$ which is regarded as the first one, but they are marked in editions with Marmitta's commentary (1491 and 1492) ${ }^{\mathbf{8 7}}$ and, on a regular basis,

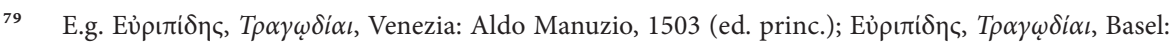

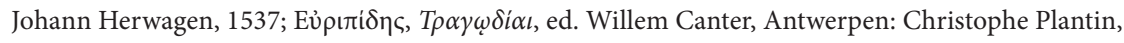
1571.

$80 \quad$ See n. 2.

81 Euripides poeta tragicorum princeps in Latinum sermonem conversus, ed., trad. et comm. Caspar Stiblin, Basel: Johann Oporinus, 1562.

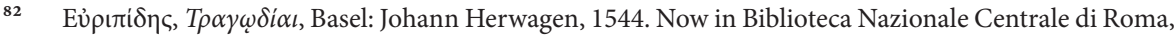
IT-RM0267 71. 3.B.21.

$83 \quad$ Minturno, De poeta, pp. 253-255.

84 See, e.g., codex Vaticanus (Biblioteca Apostolica Vaticana, Città del Vaticano, Urb. Lat. 355, 14th century). On Trevet's commentary, see, e.g., Alessandro Lagioia, "Introduzione", in Nicola Trevet, Commento all'Oedipus di Seneca, ed. by Alessandro Lagioia, Bari 2008, pp. IX-XXXIX.

85 Interestingly, it does not occur in the corpus of texts today regarded as the basis for E and A-tradition, which, in turn, form the basis for the $\Omega$ reading of the ten plays preserved under Seneca's name, namely, in codex Etruscus (Biblioteca Medicea Laurenziana, Firenze, Plut. 37.13, late 11th century), which represents E, and in codex Parisinus (Bibliothèque Nationale, Paris, Lat. 8260, first half of 13th century), codex Cantabrigensis (Corpus Christi College, Cambridge, 406, early 13th century), codex Scorialensis (Biblioteca Real, Escorial, T III 11, second half of the 14th century), and codex Vaticanus (Biblioteca Apostolica Vaticana, Città del Vaticano, Vat. Lat. 2829, early 14th century), which all belong to A. In this group of manuscripts, acts are marked occasionally only in codex Parisinus (Bibliothèque Nationale, Paris, Lat. 8031, 15th century). Manuscripts of Seneca's tragedies are discussed in more detail in Alexander P. MacGregor, “The Manuscripts of Seneca's Tragedies: A Handlist”, in Aufstieg und Niedergang der römischen Welt, vol. II 32.2, ed. by Wolfgang Haase, Berlin and New York 1985, pp. 1135-1241. See also: Otto Zwierlein, Prolegomena zu einer kritischen Ausgabe der Tragödien Senecas, Wiesbaden 1984, pp. 6-181; Robert H. Philp, “The Manuscript Tradition of Seneca's Tragedies”, The Classical Quarterly 18 (1968), no. 1, pp. 150-179; Richard John Tarrant, “Introduction”, in Seneca, Agamemnon, pp. 23-86.

86 L. Anaeus Seneca, Tragoediae, ed. Andreas Belfortis, [Ferrara, ca 1484].

87 L. Anaeus Seneca, Tragoediae, ed. et comm. Gellio Bernardino Marmitta, Lyon: Anthonius Lambillon, Marinus Sarazin, 1491; Venezia: Lazzaro Suardi, 1492. 
in later editions. ${ }^{\mathbf{8 8}}$ In fact, Roman tragedies, like Greek ones, do not conform to one structural model, and although in the 16th-century editions they are divided into five acts, Seneca's Oedipus can be divided into six acts ${ }^{89}$ because of the additional chorus part, while the division of Phoenissae, which lacks choruses, is disputable. ${ }^{90}$

There are also other examples of unusual prologues in Jesuit tragedies printed in the first decades of the 17th century. The prologue to Sedecias, a play by Luís da Cruz SI (1543-1604), is closest to Pontanus' approach. This is the only tragedy in the collection, ${ }^{91}$ which was prepared for printing (1605) shortly before the author's death, but the play was written much earlier, in $1570 .{ }^{92}$ It has chorus parts, but the prologue-delivered by persona protatica (Angelus), motivated by the plot, and mimetic in character - is placed as a separate part before act one, as in Pontanus and in the 1562 edition of Euripides mentioned above. Examples of a different kind can be found in passages delivered by personae protaticae in Crispus (1597, ed. princ. $1601^{93}$ ) by Bernardino Stefonio SI (1560-1620) and in the first edition of Carthaginenses (1608 or 1609, ed. princ. $1614^{94}$ ) by Denis Petau SI (1583-1652). Although both pieces are modelled on Seneca's dramas, the passages do not comprise the entire first act but only the first scene. It can be hypothesised that this compositional decision was inspired by reading some of Euripides' prologues, where, apart from personae protaticae, also other characters take the floor, who actually take part in the action. Stefonio might have referred in particular to the prologue of Euripides' Hippolytus (the plot of Crispus is based on the story of Hippolytus, Phaedra, and

88 For editions that predate Pontanus' poetics, L. Anaeus Seneca, Tragoediae, ed. et comm. Gellio Bernardino Marmitta, Daniele Gaetani, Venezia: Matteo Capcasa 1493; L. Anaeus Seneca, Tragoediae, ed. Benedetto Riccardini, Firenze: Filippo Giunta, 1506, 1513; L. Anaeus Seneca, Tragoediae, ed. et comm. Gellio Bernardino Marmitta, Daniele Gaetani, Jodocus Badius Ascensius, [Paris]: Jodocus Badius Ascensius, 1514; L. Anaeus Seneca, Scenicae tragoediae, ed. Gerolamo Avanzi, Venezia: Aldo Manuzio, Andrea Torresano, 1517; In L. Annaei Senecae Cordubensis poetae gravissimi Tragoedias.

89 Anthony J. Boyle, "Commentary", in Seneca, Oedipus, ed., transl., and comm. by Anthony J. Boyle, Oxford 2011, p. 335; Tomasz Sapota and Iwona Słomak, "Komentarz", in L. Annaeus Seneca, Edyp. Oedipus, ed., transl., comment., and introd. by Tomasz Sapota and Iwona Słomak, Katowice 2017, p. 202.

90 Tomasz Sapota and Iwona Słomak, “Kobiety fenickie’ Seneki - kompozycja, wzorce, tematyka”, in iid., "Kobiety fenickie” Lucjusza Anneusza Seneki. Opracowanie monograficzne, Katowice 2019, pp. 36-58.

91 The collection also includes a comedy, an eclogue, and tragicomedies; the generic purity of Sedecias is emphasised in the preface by the author himself; Luís da Cruz, Tragicae comicaeque actiones, Lyon: Horace Cardon, 1605 , fol. ${ }^{* *} 4 \mathrm{v}$.

92 Manuel José de Sousa Barbosa, "Introdução", in Luís da Cruz, Teatro, t. 1: Sedecias, ed. by Manuel José de Sousa Barbosa, Coimbra 2009, p. 14; Joaquín Pascual Barea, "Neo-Latin Drama in Spain, Portugal and Latin America", in Neo-Latin Drama, p. 624.

93 Bernardino Stefonio, Crispus, Roma: Carlo Vullietti, 1601; Lucia Strappini, "Introduzione”, in Bernardino Stefonio, Crispus. Tragoedia, ed. by Lucia Strappini, paratextual appendix ed. by Luigi Trenti, Rome 1998, pp. I-X; Jean-Frédéric Chevalier, "Neo-Latin Theatre in Italy”, in Neo-Latin Drama, p. 97.

94 Denis Petau, Carthaginienses, La Flèche: Jacques Rezé, 1614. See also Iwona Słomak, "Wstęp”, in Denis Petau, Carthaginenses. Kartagińczycy, ed., transl., comment., and introd. by Iwona Słomak, Katowice 2019, pp. 14-16. 
Theseus; Phaedrae Umbra and Malus Daemon appear in scene one). Petau modified the composition in later editions of Carthaginenses: ${ }^{95}$ he added a chorus after the part delivered by persona protatica, thus bringing the drama closer to the Senecan model. His later tragedy Sisaras, ${ }^{96}$ also with persona protatica, was composed according to the same principles. Stefonio, in turn, did not change the structure of Crispus. ${ }^{97}$ However, in his earlier play S[ancta] Symphorosa of 1591, published after his death (1655), there is a comic prologue delivered to the audience by persona protatica (Sibylla Tiburtina); even though the work was published as a tragedy, the prologue explains that the poet actually combined elements of two genres: tragedy and comedy. ${ }^{98}$ Unusual prologues can also be found in Cyrus (published in 1619), ${ }^{99}$ a tragedy by Jean-Henry Aubery SI (died 1652), and in Hermenigildus (published in 1620$)^{\mathbf{1 0 0}}$ by Nicolas Caussin (1583-1651). Here, the prologues are placed before act one or the first part of the play, but they are written in the epic metre and modelled on epic prologues: they contain a brief summary and the poet's invocation to the Muses or to God. In this case, unlike in those discussed above, one can speak of an intentional deviation from the traditional model. Aubery writes the dialogues in dactylic hexameter and apparently chooses to add a matching prologue. Moreover, in the preface to the reader, the author observes that his play can be called tragica epopoeia or epica tragoedia. ${ }^{101}$ Caussin, in turn, refers to Hermenigildus as actio oratoria, although he includes it in a collection of tragedies (on the basis of the theme of the play): in fact, only the chorus parts are written in poetry, and the dialogues are in prose. This is why the author does not feel obliged to follow the rules for the tragic prologue; in addition, he uses the epic metre in argumentum to Felicitas, ${ }^{\mathbf{1 0 2}}$ a regular tragedy published in the same collection. Except for the last two, all these examples indicate that the division into acts and the function of the prologue in a regular tragedy were subject to discussion in times when both Seneca and Greek tragedians were widely read in colleges, ${ }^{\mathbf{1 0 3}}$ and that forms which now appear in various ways unusual often resulted from a careful reconsideration of the ancient model.

Returning to the problem of the chorus, absent from Pontantus' tragedy and ignored in his poetics, one may ask whether, perhaps, the author excluded the chorus

Iwona Słomak, "Aparat krytyczny”, in Denis Petau, Carthaginenses. Kartagińczycy, pp. 53-63.

Denis Petau, Sisaras, in id., Opera poetica, Paris: Sébastien Cramoisy, 1620. See also: Słomak, "Wstęp", pp. 14-15.

See, e.g., Bernardino Stefonio, Crispus, Milano: Giovanni Battista Bidelli, 1617.

Bernardino Stefonio, S[ancta] Symphorosa, Data in Collegio Romano anno MDXCI. Nunc primum typis mandata, Roma: Ignatius de Lazaris, 1655, p. 7-8.

Jean Henry Aubery, Cyrus, Toulouse: Veuve de Jacques Colomiez, 1619. For information about the author, see Sommervogel, Bibliothèque, vol. 1, col. 619-621.

Nicolas Caussin, Hermenigildus, in id., Tragoediae sacrae, Paris: Sébastien Cramoisy, 1620. See also Jean-Frédéric Chevalier, "Jesuit Neo-Latin Tragedy in France”, in Neo-Latin Drama, p. 465.

Aubery, Cyrus, pp. 13-14.

Nicolas Caussin, Felicitas, p. 1-2, in id., Tragoediae sacrae.

See n. 2. 
in the belief that it did not build the plot and therefore was not an obligatory part of the play, an opinion expressed by Scaliger and later by, among others, Donati. ${ }^{\mathbf{1 0 4}}$ This belief might have been strengthened by his reading of Seneca's plays, where the chorus not only does not contribute to the development of the action but, in some cases, is not justified by the plot and is difficult to ascribe to concrete characters of the world of the play. ${ }^{105}$ A remark made by Pierre Mousson SI (1561-1637), who in his tragedies published in 1621 (presented on stage in the years 1606-1611) ${ }^{\mathbf{1 0 6}}$ abandoned the chorus altogether (at the same time admitting that it was not a commonly accepted practice), indirectly points to the fact that the chorus parts in Jesuit tragedies of the turn of the 17th century were often unrelated to the theme of the plays:

Ideo choros a me neglectos, quod cum tragoediae exhiberentur, non facile, qui eos pronunciaret, e florentissima iuventute quenquam reperires; neque populum nisi interposita aliqua e vetere patrum memoria historiola, aut apologo ad tempus accomodato, aut Pyrrhica saltatione, aut alio quovis genere oblectationis dilabentem forte teneres. Quae omnia quoniam in actione posita tantum sunt; typis consignari, mandarique non possunt. ${ }^{107}$

[I resigned from the chorus parts because among excellent young people, it is not easy to find someone who could sing them during the performance of a tragedy; besides it is difficult to keep spectators who move around in place without inserting a story from the past, a suitable tale, a warriors' dance, or another form of entertainment. It is all there on the stage, but one cannot print it.]

Finally, it is possible that Pontanus modelled his drama partly on Seneca's Phoenissae (= Thebais). Institutionum poeticarum libri tres were published a year after Delrío's edition of Seneca’s tragedies (1593), supplemented by, among others, a general discussion of the genre, and in 1594, Delrío published a new commentary to his plays. ${ }^{\mathbf{1 0 8}}$ He included there a short praise of Phoenissae, ${ }^{\mathbf{1 0 9}}$ which later might have spread among Jesuits, especially in view of the fact that Delrío's editions of Seneca's tragedies were among those recommended for the use in colleges. ${ }^{\mathbf{1 1 0}}$ Still, it seems unlikely that Pontanus read it before publishing his poetics, as he does not refer to

104 Scaliger (Poetices libri septem, pp. 14-15) does not include the chorus in partes primariae of a play, such as protasis, epistasis, catastasis, or catastrophe, but in partes accessoriae, which do not contribute to the plot, such as, for instance, argumentum and the comic prologue. See also Donati, Ars poetica, p. 279.

D.E. Hill, “Seneca’s Choruses", Mnemosyne 53 (2000), no. 5, pp. 561-587.

Pierre Mousson, Tragoediae. Die lateinischen Tragödien von Pierre Mousson S.J., ed. by Rrudolf Rieks and Klaus Geus, Frankfurt am Main 2000, p. 30. See also Chevalier, “Jesuit Neo-Latin Tragedy”, pp. 467-468. Mousson, Tragoediae, p. 100.

Delrío, Syntagma tragoediae Latinae in tres partes; id., Syntagmatis tragici pars ultima seu novus commentarius, Antwerpen: Veuve de Christophe Plantin, Jan Moretus, 1594.

Delrío, Syntagmatis tragici pars ultima, p. 136.

"Catalogus commentariorum" (1604), in Pachtler, Ratio studiorum, p. 15. 
it as a source. In the new commentary, Delrío not only maintains his earlier opinion that Seneca, for some reason, did not finish Phoenissae, ${ }^{\mathbf{1 1 1}}$ but also emphasises that the lack of the chorus, obligatory in tragedy, additionally indicates that the work is incomplete:

Ab hoc versiculo desunt cetera, ut et chori. Noli putare poetam voluisse tragoediam sine choris ullis edere, quare frivolum inde argumentum petitur, ad probandum hanc fabulam Senecae nostri non esse. ${ }^{112}$

[After this line, the continuation is missing, and the choruses. One cannot assume that the poet intended to publish a tragedy completely devoid of the chorus parts, so it is a useless argument to show that the tragedy was not written by our Seneca.]

However, Pontanus might have been familiar with the earlier 1576 version of Delrío's edition, where he merely remarks on the missing ending of Phoenissae. Here, as in other editions of this period, the play is divided into four acts, and act five is regarded as missing. ${ }^{113}$ Delrío ends this passage with a clear reference to Lipsius, a friend and rival to whom he dedicates his work. ${ }^{114}$ Indeed, on the basis of, among others, formal features of Phoenissae, Lipsius argues that the play is structurally close to comedy rather than merely incomplete, and that it was written by somebody else than the author of the other tragedies attributed to Seneca. At the same time, he considers it the best in this group of works:

Oeconomia diversa, sine choris, sine interruptione, continua quasi ad comicam. Scriptio tota uniformis, simplex, sine carminum ulla varietate, sed scriptio, ita me Deus amet, alta, docta, grandis; et quae suo iure ambulet in cothurnis. Nihil usquam iuvenile, arcessitum, fucatum; phrasis et verba lecta; sententiarum mira et inopinata acumina.... Quid tale in aliis? Audebo rem dicere. Scripti gemmula haec est.... Quidquid huius est, tollenda sane ea, nec ultra calcanda pedibus ignari vulgi. Vos, Critici, ponite et habete audacter inter prima Romana scripta. ${ }^{115}$

[The composition is different, without choruses, without breaks, continuous as in a comic play. The text is uniform, simple, not diversified with songs, but Lord knows it is a text that is lofty, learned, solemn, and in its own way walking in cothurni. There is nothing childish

111 Cf. In L. Annaei Senecae Cordubensis poetae gravissimi Tragoedias, p. 239.

112 Delrío, Syntagmatis tragici pars ultima, p. 151. The lack of the chorus is also mentioned, for instance, in the Ascensius edition (Seneca, Tragoediae (1514), fol. LXVIv, LXXXIv).

113 This applies to the Marmitta, Marmitta and Gaetani, Riccardini, Ascensius, and Avanzi editions mentioned above; see n. 88 .

114 Delrío, Syntagmatis tragici pars ultima, pp. 3-4.

115 Justus Lipsius, Animadversiones in tragoedias quae L. Annaeo Senecae tribuuntur, Leiden: Franciscus Raphelengius, 1588 , pp. 6-7. 
about it, nothing stilted or too fancy. Excellent style and choice of words. Astonishing, amazing acuity of thought.... What similar do others have? I dare to say it is a literary gem.... Whatever the truth is, it deserves to be appreciated and not to be trampled on by a crowd of ignorants any longer. You, Critics, place it boldly among the best Roman works.]

The theory according to which the chorus parts were of no significance to the dramatic plot-unsupported by Scaliger or Donati with more extensive evidence or examples-might have been a source of inspiration for Pontanus. It is more likely, though, that he resolved not to treat the chorus as an obligatory element in tragedy on the basis of Phoenissae and Lipsius' comments. ${ }^{\mathbf{1 1 6}}$ It is also worth mentioning that Lipsius' Animadversiones was later recommended in colleges as a commentary to Seneca's tragedy, along with Delrío's edition. ${ }^{117}$ It was brought out early enough (1588) for Pontanus to read it before publishing his poetics. Although he wrote his tragedy earlier (1587), ${ }^{118}$ he did not publish it until $1600 .{ }^{119}$ Its earlier version is unknown, so it is impossible to state with certainty that it had no chorus from the outset; in fact, in the middle of another short play (Immolatio Isaac of 1590), the author planned a vocal or instrumental piece ${ }^{\mathbf{1 2 0}}$ but did not attach the text of the song. Finally, in his later Attica bellaria, Pontanus leans towards Lipsius' opinion on Phoenissae:

Anonymus praeterea quidam Thebaidem composuit, laudatam tragoediam, quam sunt qui Senecae adscribant, et vulgo pro Seneciana habetur, et cum aliis, non integra licet, circumfertur. Doctiores negant. ${ }^{121}$

[Apart from that, Thebais, a highly-regarded tragedy, was written by an anonymous author. Some attribute it to Seneca, and it is commonly regarded, with other plays, as Senecan, albeit unfinished. The more illustrious scholars disagree.]

A comparative reading of one of the first poetics of Societas Iesu fathers and the first published Jesuit tragedy-situated against the background of the preserved

116 Even today, some scholars regard Phoenissae as incomplete or fragmentary; however, a careful reading of the text does not support this view. Formally, the play is unique among the preserved ancient dramatic works, but most of them have been lost. At present, one cannot state with certainty whether Senecan Phoenissae-assuming that the play is complete-could be regarded as a tragedy at the time when it was written; Sapota and Słomak, "Kobiety fenickie' Seneki”. des pièces représentées et des documents conservés (1555-1773), t. 1: Première partie: 1555-1728, Stuttgart 1983, no. 247, p. 28.

"Catalogus commentariorum" (1604), p. 15.

Jean-Marie Valentin, Le Théâtre des Jésuites dans les pays de langue allemande. Répertoire chronologique Pontanus, Poeticarum institutionum libri III. Editio tertia, pp. 507-556.

Ibid., s. 575; cf. Pontanus, Poeticarum institutionum libri tres, p. 545.

Jakob Pontanus, Attica bellaria sive litteratorum secundae mensae ... pars secunda, Augsburg: Andreas Aperger, 1617, pp. 531-532. 
ancient poetics of the dramatic genre, the oldest preserved tragedies, and selected studies used by Pontanus-demonstrates that, even if formally Eleazarus departs from some ancient tragic models, the author does not seem to have aimed at abandoning the Greek-Roman tradition. On the contrary, it seems that he understood it well enough to be aware of its diversity and difficulties emerging when one sets it against incomplete ancient theoretical approaches. This may have been the reason why he did not aim at copying the form of any particular ancient work; instead, he relied on general rules, established on the basis of many different sources. In some respects, the resulting model of tragedy was not the one most commonly applied in ancient texts or in works by Pontanus' contemporaries. However, some of its elements which apparently depart from tradition do not, in fact, violate generic rules that were or might have been used by ancient tragedians. Thus, Pontanus' tragedy and his theoretical approach should be regarded as classical in nature.

\section{Bibliography}

\section{Manuscript sources}

"Catalogus triennalis" (1616-1622) in Ordinationes praepositorum generalium, provincialium, visitatorum et responsa Romana Provinciae Polonae et Litvaniae saeculis XVI-XVII data, Archivum Societatis Iesu Cracoviense, 496, pp. 910-919.

Codex Ambrosianus, Biblioteca Ambrosiana, Milano, D 276 inf.

Codex Cantabrigensis, Corpus Christi College, Cambridge, 406.

Codex Etruscus, Biblioteca Medicea Laurenziana, Firenze, Plut. 37.13.

Codex Parisinus, Bibliothèque Nationale, Paris, Lat. 8031.

Codex Parisinus, Bibliothèque Nationale, Paris, Lat. 8260.

Codex Scorialensis, Biblioteca Real, Escorial, T III 11.

Codex Vaticanus, Biblioteca Apostolica Vaticana, Città del Vaticano, Urb. Lat. 355.

Codex Vaticanus, Biblioteca Apostolica Vaticana, Città del Vaticano, Vat. Lat. 2829.

\section{Printed sources}

Aubery, Jean Henry, Cyrus, Toulouse: Veuve de Jacques Colomiez, 1619.

Caussin, Nicolas, Felicitas, in Nicolas Caussin, Tragoediae sacrae, Paris: Sébastien Cramoisy, 1620.

Caussin, Nicolas, Hermenigildus, in Nicolas Caussin, Tragoediae sacrae, Paris: Sébastien Cramoisy, 1620.

Cruz, Luís da, Tragicae comicaeque actiones, Lyon: Horace Cardon, 1605.

Delrío, Martín Antonio, Syntagma tragoediae Latinae in tres partes distinctum, Antwerpen: Veuve de Christophe Plantin, Jan Moretus, 1593. 
Delrío, Martín Antonio, Syntagmatis tragici pars ultima seu novus commentarius, Antwerpen: Veuve de Christophe Plantin, Jan Moretus, 1594.

Donati, Alessandro, Ars poetica, Roma: Guglielmo Faciotti, 1631.

Euripides poeta tragicorum princeps in Latinum sermonem conversus, ed., trad. et comm. Caspar Stiblin, Basel: Johann Oporinus, 1562.

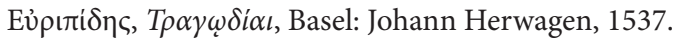

Eủ

Eủpı $\pi i \delta \eta \varsigma, T \rho \alpha \gamma \omega \delta i \alpha \iota$, ed. Willem Canter, Antwerpen: Christophe Plantin, 1571.

Eủ

Galluzzi, Tarquinio, Virgilianae vindicationes et Commentarii tres de tragoedia, comoedia, elegia, Roma: Alessandro Zanetti, 1621.

In L. Annaei Senecae Cordubensis poetae gravissimi Tragoedias decem ... amplissima adversaria, ed. et comm. Martín Antonio Delrío, Antwerpen: Christophe Plantin, 1576.

Lipsius, Justus, Animadversiones in tragoedias quae L. Annaeo Senecae tribuuntur, Leiden: Franciscus Raphelengius, 1588.

Maggi, Vincenzo, Bartholomaeus Lombardus, In Aristotelis librum de poetica communes explanationes, Venezia: Vincenzo Valgrisi, 1550.

Minturno, Antonio Sebastiano, De poeta, Venezia: Francesco Rampazetto, 1559.

Petau, Denis, Carthaginienses, La Flèche: Jacques Rezé, 1614.

Petau, Denis, Sisaras, in Denis Petau, Opera poetica, Paris: Sébastien Cramoisy, 1620.

Pontanus, Jacob, Attica bellaria sive litteratorum secundae mensae ... pars secunda, Augsburg: Andreas Aperger, 1617.

Pontanus, Jacob, Eleazarus Machabaeus. Tragoedia sacra, in J. Pontanus, Poeticarum institutionum libri III. Editio tertia cum auctario, et indice hactenus desiderato. Eiusdem Tyrocinium poeticum cum supplemento, Ingolstadt: Adam Sartorius, 1600, pp. 507-556.

Pontanus, Jacob, Poeticarum institutionum libri III. Editio tertia cum auctario, et indice hactenus desiderato. Eiusdem Tyrocinium poeticum cum supplemento, Ingolstadt: Adam Sartorius, 1600.

Pontanus, Jacob, Poeticarum institutionum libri tres. Eiusdem Tyrocinium poeticum, Ingolstadt: David Sartorius, 1594.

Ratio atque institutio studiorum, Roma: Collegium Societatis Iesu, 1591.

Robortello, Francesco, In librum Aristotelis de arte poetica explicationes, Firenze: Lorenzo Torrentino, 1548.

Scaliger, Julius Caesar, Poetices libri septem, [Lyon]: Antoine Vincent, 1561.

Seneca, L. Anaeus, Scenicae tragoediae, ed. Gerolamo Avanzi, Venezia: Aldo Manuzio, Andrea Torresano, 1517.

Seneca, L. Anaeus, Tragoediae, ed. Andrea Belfortis, [Ferrara, ca 1484].

Seneca, L. Anaeus, Tragoediae, ed. Benedetto Riccardini, Firenze: Filippo Giunta, 1506, 1513.

Seneca, L. Anaeus, Tragoediae, ed. et comm. Gellio Bernardino Marmitta, Lyon: Anthonius Lambillon, Marinus Sarazin, 1491.

Seneca, L. Anaeus, Tragoediae, ed. et comm. Gellio Bernardino Marmitta, Venezia: Lazzaro Suardi, 1492.

Seneca, L. Anaeus, Tragoediae, ed. et comm. Gellio Bernardino Marmitta, Daniele Gaetani, Venezia: Matteo Capcasa 1493. 
Seneca, L. Anaeus, Tragoediae, ed. et comm. Gellio Bernardino Marmitta, Daniele Gaetani, Jodocus Badius Ascensius, [Paris]: Jodocus Badius Ascensius, 1514.

Stefonio, Bernardino, Crispus, Milano: Giovanni Battista Bidelli, 1617.

Stefonio, Bernardino, Crispus, Roma: Carlo Vullietti, 1601.

Stefonio, Bernardino, S[ancta] Symphorosa. Data in Collegio Romano anno MDXCI. Nunc primum typis mandata, Roma: Ignatius de Lazaris, 1655.

Vettori, Pietro, Commentarii in primum librum Aristotelis de arte poetarum, Firenze: Filippo

Giunto, Bernardo Giunto, Jacopo Giunto, Julio Giunto, 1560.

Viperano, Giovanni Antonio, De poetica libri tres, Antwerpen: Christophe Plantin, 1579.

\section{Abbreviations}

Aristoteles Poetica-Aristotle, Poetics, transl. by Stephen Halliwell, Longinus, On the Sublime, transl. by W.H. Fyfe, rev. by Donald Russel, Demetrius, On Style, transl. by Doreen C. Innes, based on W. Rhys Roberts, Cambridge (Mass.)-London 1999.

Donatus Ad Terentii Adriam; De comoedia-Aelius Donatus, Quod fertur Commentum Terenti, rec. Paul Wessner, vol. 1, Leipzig 1902.

Euanthius-in Aelius Donatus, Quod fertur Commentum Terenti, rec. Paul Wessner, vol. 1, Leipzig 1902.

Horatius Ars poetica-Quintus Horatius Flaccus, Opera, ed. Stefan Borzsák, Leipzig 1984.

Seneca Hercules furens-Lucius Annaeus Seneca, Tragoediae. Incertorum auctorum Hercules Oetaeus. Octavia, rec. Otto Zwierlein, Oxford 1986.

Seneca Hercules Oetaeus-Lucius Annaeus Seneca, Tragoediae. Incertorum auctorum Hercules Oetaeus. Octavia, rec. Otto Zwierlein, Oxford 1986.

Seneca Troades-Lucius Annaeus Seneca, Trojanki. Troades, transl. and ed. by Tomasz Sapota and Iwona Słomak, Katowice 2016.

Biblical references-Biblia sacra vulgatae editionis, Frankfurt am Main 1826.

\section{Studies}

Bielmann, Joseph., "Die Dramentheorie und Dramendichtung des Jakobus Pontanus S.J. (1542-1626)”, Literaturwissenschaftliches Jahrbuch der Görres-Gesellschaft 3 (1928), pp. 45-85. Blum, Paul Richard, “Jacobus Pontanus SJ”, in Deutsche Dichter der frühen Neuzeit (1450-1600). Ihr Leben und Werk, ed. by Stephan Füssel, Berlin 1993, pp. 626-635.

Boyle, Anthony J., "Commentary", in Seneca, Oedipus, ed., transl., and comment. by Anthony J. Boyle, Oxford 2011, pp. 95-361.

Carlson, Marvin, Theories of the Theatre: A Historical and Critical Survey from the Greeks to the Present, Ithaca and London 1984.

Chevalier, Jean-Frédéric, "Jesuit Neo-Latin Tragedy in France", in Neo-Latin Drama and Theatre in Early Modern Europe, ed. by Jan Bloemendal and Howard B. Norland, Leiden and Boston 2013, pp. 415-569. 
Chevalier, Jean-Frédéric, "Neo-Latin Theatre in Italy", in Neo-Latin Drama and Theatre in Early Modern Europe, ed. by Jan Bloemendal and Howard B. Norland, Leiden and Boston 2013, pp. 25-101.

Dainville, François de, Léducation des Jésuites (XVI ${ }^{e}-X V I I I^{e}$ siècles), ed. by Marie-Madelaine Compère, Paris 1978.

Hill, D.E., "Seneca’s Choruses", Mnemosyne 53 (2000), no. 5, pp. 561-587.

Ijsewijn, Jozef, "Symbola ad studium theatri Latini Societatis Iesu”, Revue Belge de Philologie et d'Histoire 43 (1965), no. 3, pp. 946-960.

Lagioia, Alessandro, "Introduzione", in Nicola Trevet, Commento all'Oedipus di Seneca, ed. by Alessandro Lagioia, Bari 2008, pp. IX-XLII.

Leinsle, Ulrich G., "Jacobus Pontanus SJ (1542-1626). Humanismus und 'pietas' in der Spätrenaissance", Beiträge zur Geschichte des Bistums Regensburg 43 (2009), pp. 81-99.

MacGregor, Alexander P., "The Manuscripts of Seneca's Tragedies: A Handlist”, in Aufstieg und Niedergang der römischen Welt, vol. II 32.2, ed. by Wolfgang Haase. Berlin and New York 1985, pp. 1135-1241.

Mahlmann-Bauer, Barbara, "Jakob Pontanus in Augsburg. Seine Schülergespräche, seine Poetik und sein Drama 'Opferung Isaaks'”, in Jakob Bidermann und sein 'Cenodoxus'. Der bedeutendste Dramatiker aus dem Jesuitenorden und sein erfolgreichstes Stück, ed. by Helmut Gier, Regensburg 2005, pp. 15-59.

Mousson, Pierre, Tragoediae. Die lateinischen Tragödien von Pierre Mousson S.J., ed. by Rudolf Rieks and Klaus Geus, Frankfurt am Main 2000.

Pachtler, Georg Michael, Ratio studiorum et institutiones scholasticae Societatis Iesu per Germaniam olim vigentes collectae, concinnatae, dilucidatae, vol. 4, Berlin 1894.

Pascual Barea, Joaquín, "Neo-Latin Drama in Spain, Portugal and Latin America", in Neo-Latin Drama and Theatre in Early Modern Europe, ed. by Jan Bloemendal and Howard B. Norland, Leiden and Boston 2013, pp. 545-631.

Philp, Robert H., “The Manuscript Tradition of Seneca's Tragedies”, The Classical Quarterly 18 (1968), no. 1, pp. 150-179.

Rädle, Fidel, "Jesuit Theatre in Germany, Austria and Switzerland", in Neo-Latin Drama and Theatre in Early Modern Europe, ed. by Jan Bloemendal and Howard B. Norland, Leiden and Boston 2013, pp. 185-292.

Sapota, Tomasz and Iwona Słomak, "'Kobiety fenickie’ Seneki - kompozycja, wzorce, tematyka”, in Tomasz Sapota and Iwona Słomak, "Kobiety fenickie" Lucjusza Anneusza Seneki. Opracowanie monograficzne, Katowice 2019, pp. 36-58.

Sapota, Tomasz and Iwona Słomak, "Komentarz", in L. Annaeus Seneca, Edyp. Oedipus, ed., transl., comment., and introd. by Tomasz Sapota and Iwona Słomak, Katowice 2017, pp. 144-205.

Słomak, Iwona, "Aparat krytyczny”, in Denis Petau, Carthaginenses. Kartagińczycy, ed., transl., comment., and introd. by Iwona Słomak, Katowice 2019, pp. 53-64.

Słomak, Iwona, "Wstęp”, in Denis Petau, Carthaginenses. Kartagińczycy, ed., transl., comment., and introd. by Iwona Słomak, Katowice 2019, pp. 7-48.

Sommervogel, Carlos, Bibliothèque de la Compagnie de Jésus. Bibliographie, Brussels and Paris 1890-1932. 
Sousa Barbosa, Manuel José de, "Introdução", in Luís da Cruz, Teatro, t. 1: Sedecias, ed. by Manuel José de Sousa Barbosa, Coimbra 2009, pp. 5-44.

Strappini, Lucia, "Introduzione", in Bernardino Stefonio, Crispus. Tragoedia, ed. by Lucia Strappini, paratextual appendix ed. by Luigi Trenti, Rome 1998, pp. I-XXVII.

Tarrant, Richard John, "Commentary", in Seneca, Agamemnon, ed. with a comment. by Richard John Tarrant, Cambridge 1976, pp. 156-361.

Tarrant, Richard John, "Introduction", in Seneca, Agamemnon, ed. with a comment. by Richard John Tarrant, Cambridge 1976, pp. 3-96.

Valentin, Jean-Marie, Le Théâtre des Jésuites dans les pays de langue allemande. Répertoire chronologique des pièces représentées et des documents conservés (1555-1773), vol. 1: Première partie: 1555-1728, Stuttgart 1983.

Zwierlein, Otto, Prolegomena zu einer kritischen Ausgabe der Tragödien Senecas, Wiesbaden 1984.

\section{IWONA SŁOMAK}

ث. Uniwersytet Śląski w Katowicach / University of Silesia in Katowice, Poland

(D) https://orcid.org/0000-0002-6940-9520

@ iwona.slomak[at]us.edu.pl

Iwona Słomak-Assistant Professor, University of Silesia in Katowice, Institute of Literary Studies, Faculty of Humanities. Research interest: ancient and Neo-Latin drama, poetics, and rhetoric; reception of ancient literature. Main publications: three monographs: Retoryka "miłosnej batalii". "Wojsko serdecznych nowo rekrutowanych afektów" Hieronima Falęckiego (2017), "Phoenix rhetorum" Jana Kwiatkiewicza (2016), (with Tomasz Sapota) "Kobiety fenickie” Lucjusza Anneusza Seneki (2019). Editions with translations and commentaries of: Denis Petau's Carthaginenses (2019), (with Tomasz Sapota) Seneca's Oedipus (2017), and Troades (2016).

This research received no specific funding. 